\title{
Mutational and Transcriptional Analysis of the Type III Secretion System of Bradyrhizobium japonicum
}

\author{
Andrea Krause, Anke Doerfel, and Michael Göttfert \\ Institut für Genetik, Technische Universität Dresden, Mommsenstraße 13, 01062 Dresden, Germany
}

Submitted 15 January 2002. Accepted 9 August 2002.

\begin{abstract}
Sequencing the symbiotic region of Bradyrhizobium japonicum revealed a gene cluster (tts) encoding a type III secretion system (TTSS) that is similar to those found in Mesorhizobium loti MAFF303099 and Rhizobium strain NGR234. In addition to genes that are likely to encode structural core components of the TTSS, the cluster contains several open reading frames that are found exclusively in rhizobia or that are specific to $B$. japonicum. Depending on the host, mutations within this cluster affected nodulation capacity to different extents. One of the genes likely encodes a transcriptional activator (TtsI) of the two-component regulatory family. Upstream of $t$ tsI, a nod box promoter was identified. Expression of $t$ ts $I$ could be induced by genistein. This induction depended on the transcriptional activator protein NodW as well as the nodD1nodD2nolA gene region. TtsI was found to be involved in transcriptional regulation of the $t$ ts gene cluster. Sequence comparison revealed a conserved tts box element within putative promoter regions of several genes. Here, we propose a model of the regulatory cascade leading to the induction of the $t$ ts gene cluster.
\end{abstract}

Additional keywords: nitrogenase activity, symbiosis.

Type III secretion systems (TTSS), highly conserved multiprotein complexes spanning the entire bacterial cell envelope, play an essential role in the pathogenicity of many gram-negative bacteria infecting humans, animals, and plants (Hueck 1998). In response to multiple environmental and host-derived signals, TTSS transport a wide variety of effector proteins either into the extracellular medium or into the cytoplasm of eukaryotic host cells, where they often provoke disease symptoms (Galán and Collmer 1999; Hueck 1998).

TTSS had previously been thought to be unique to pathogenic bacteria, but recently, these systems have been identified in rhizobia (Marie et al. 2001). TTSS have been found in Rhizobium strain NGR234 (Freiberg et al. 1997), in Mesorhizobium loti MAFF303099 (Kaneko et al. 2000), and in Bradyrhizobium japonicum 110spc4 (Göttfert et al. 2001). Additionally, limited sequence data suggest the presence of TTSS in Sinorhizobium fredii USDA257 (Meinhardt et al. 1993), USDA191 (Bellato et al. 1997), and HH103 (Bellato et al. 1997; Marie et al. 2001; GenBank: AY034152). In contrast, Sinorhizobium meliloti (Galibert et al. 2001) and the symbiosis island of M. loti strain R7A (Sullivan et al. 2002) do not contain such a system. Thus, TTSS are present in some but not in all rhizobia.

In response to host-derived flavonoids, rhizobia secrete proteins into the medium via the TTSS (Krishnan et al. 1995;

Corresponding author: Andrea Krause, Telephone: +49-351-46335407; Fax: +49-351-46337725; E-mail: krausea@rcs.urz.tu-dresden.de
Marie et al. 2001; Viprey et al. 1998). Until now, nopX and nopL from Rhizobium strain NGR234 (previously named nolX and $y 4 x L$ ) are the only identified genes that are known to encode such secreted proteins (Viprey et al. 1998). However, the function of the secreted proteins in the symbiotic interaction is not yet determined. Mutations in the type III gene clusters ( $t t s)$ of Rhizobium strain NGR234 and S. fredii affect nodule development. Depending on the host, symbiotic capacity of mutant strains is impaired, improved, or unaltered (Bellato et al. 1997; Meinhardt et al. 1993; Viprey et al. 1998).

Rhizobia have the unique capability to induce development of root nodules on legume plants. Within these new plant organs, the bacteria are hosted intracellularly as symbionts, finding ideal environmental conditions to reduce atmospheric nitrogen to ammonia. The development of nodules depends on the presence of plant root-derived flavonoids, which initiate a signal cascade in rhizobia (Long 2001). Perception of these compounds by rhizobia activates the transcriptional activator NodD. NodD binds to the nod box, a conserved element in the promoter region of nod genes, and triggers the expression of genes located downstream. Additionally, in B. japonicum the two-component regulatory system NodVW is required for efficient nod gene expression, which also depends on the presence of flavonoids (Göttfert et al. 1990; Loh et al. 1997). Nod proteins, in turn, carry out the synthesis of Nod factors, bacterial signals that provoke the first steps of nodule development (Long 2001).

Here, we report the analysis of the $t t s$ gene cluster from $B$. japonicum and show that the same transcriptional activators that are involved in nod gene regulation are required for expression of genes within this cluster.

\section{RESULTS}

The $t$ ts gene cluster of $\boldsymbol{B}$. japonicum contains conserved, as well as unique, open reading frames (ORFs).

Within a 47-kb region of the $B$. japonicum chromosome, ten ORFs show similarity to genes encoding TTSS in rhizobia and pathogenic bacteria (Fig. 1) (Göttfert et al. 2001). Following the nomenclature suggested by Viprey and associates (1998), these genes are named rhc (Rhizobium conserved). For the corresponding gene cluster, we propose the designation $t$ ts (type three [III] secretion).

Apart from a few rearrangements and the presence of several IS-related elements within the B. japonicum cluster, the gene order within the $t t s$ clusters of different rhizobia is relatively well conserved (Fig. 1). Besides rhc genes, several of the ORFs are conserved in all rhizobial $t t s$ clusters but are missing in pathogenic bacteria (e.g., nolB and nolU). Other ORFs are present only in some rhizobial strains. For example, nopL exists in Rhizobium strain NGR234 and B. japonicum, whereas nopX is found in Rhizobium strain NGR234 and M. loti 
MAFF303099. Additionally, some ORFs, like id199 and id274 (tentative designations), seem to be specific for B. japonicum (Fig. 1).

One of several putative operons of the $t$ ts gene cluster is preceded by a nod box promoter (Fig. 1). The deduced amino acid sequence of the first conserved ORFs downstream of this nod box has similarity to transcriptional activators of the two-component regulatory system. We suggest the designation $t$ tsI for this gene.

\section{Nodulation properties and nitrogenase activities of deletion mutants.}

To elucidate the role of the TTSS in the interaction of $B$. japonicum with its host plants, deletion mutants were constructed (Fig. 1). In mutant strains $\Delta 139$ and $\Delta 171$, only one gene-ttsI or $r h c C 1$, respectively-is deleted. The other mutants carry deletions of several genes. The symbiotic properties of the mutant strains were determined in plant infection tests with Glycine max, Vigna unguiculata, and Macroptilium atropurpureum and were compared with the phenotype of the wildtype strain.

With respect to nodule numbers, mutations do not seem to greatly influence the interaction with $V$. unguiculata (Fig. 2). G. max developed similar nodule numbers with all strains within 3 weeks but exhibited a delay in nodule development, especially with strains $\Delta 136$ and $\Delta 139$, which lack a functional ttsI gene and also, in the case of strain $\Delta 136$, several neighboring ORFs. Nodule numbers were more reduced with $M$. atropurpureum. However, most of the nodules on $M$. atropurpureum developed to an unusually large size. Nitrogenase activity per nodule increased about twofold, with the exception of nodules from plants inoculated with strain $\Delta 139$ (Table 1). With V. unguiculata but not with $G$. max, nitrogenase activity per nodule also seems to be slightly increased in combination with some mutant strains.

Expression of the $t$ ts gene cluster is inducible by genistein.

To study the expression of the $t$ ts gene cluster, translational fusions of lacZ with id205, nolU, nopL, rhcCl, rhcV, and ttsI (Fig. 1) were constructed and were integrated into the chromo-
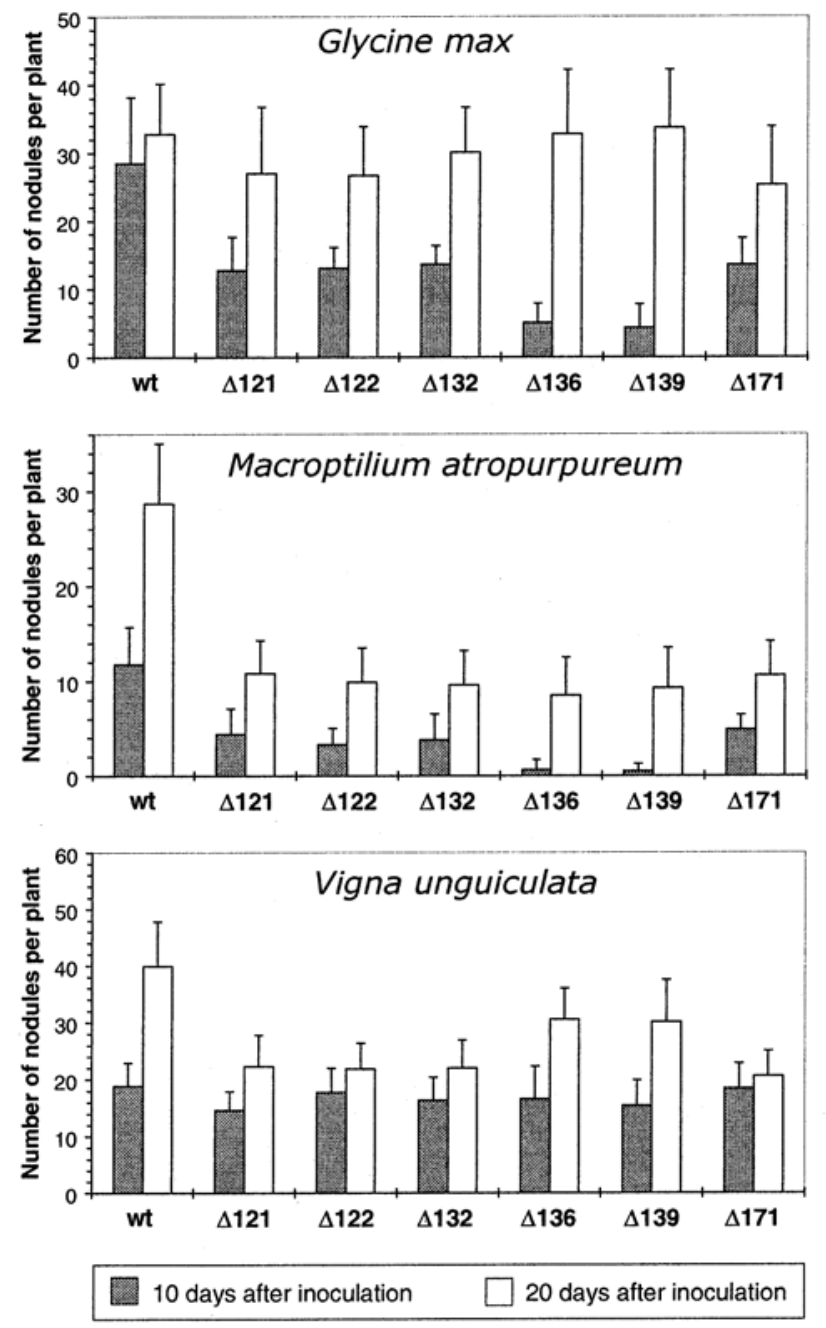

Fig. 2. Nodulation properties of Bradyrhizobium japonicum wild type and deletion derivatives. Nodule numbers (average \pm standard deviation) were determined from at least 20 plants per strain.

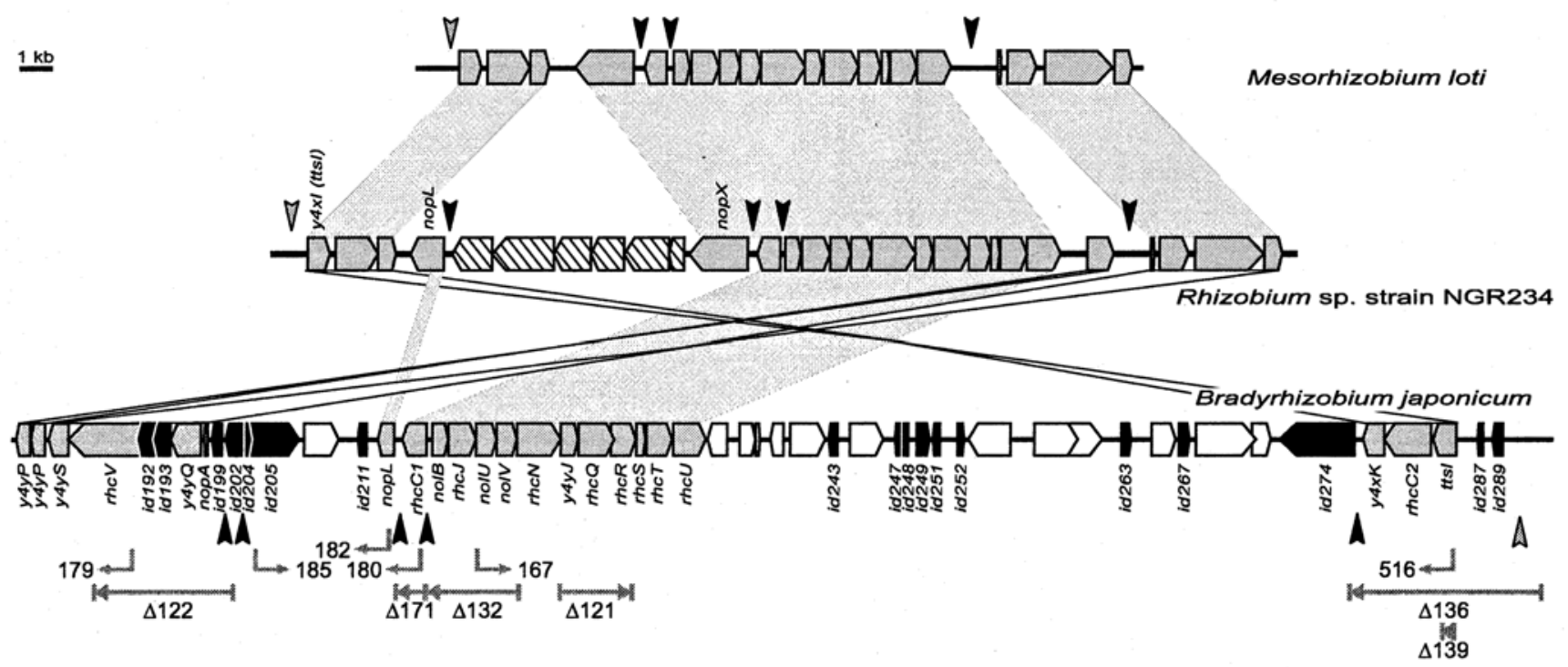

Fig. 1. Comparison of the tts gene clusters of Bradyrhizobium japonicum, Mesorhizobium loti MAFF303099, and Rhizobium strain NGR234. Open reading frames (ORFs) unique to B. japonicum are shown in black. ORFs present in Rhizobium strain NGR234 only are marked by stripes. Gray ORFs are conserved in at least two of the three strains. ORFs with similarity to IS-related elements are displayed in white. Positions of nod boxes are indicated by gray arrowheads. Black arrowheads depict positions of $t t s$ boxes. Deletions are marked by horizontal arrows. The direction of the arrows shows the orientation of the inserted $\mathrm{Km}^{\mathrm{r}}$ cassette, and the corresponding strain designations are given. Rectangular arrows indicate positions of the translational lac $Z$ fusions. 
some of the wild type as well as mutant strains 613 and $\Delta 1267$. Because $t t s I$ is part of the $t t s$ gene cluster and has similarity to transcriptional activators of the two-component regulatory family, the id205-, nolU-, nopL-, rhcC1-, and rhcV-lacZ fusion constructs were also integrated into a ttsI mutant background (strain $\Delta 139$ ). Strain 613 is a nodW mutant. In mutant $\Delta 1267$ nodD1, nodD2, and nolA are deleted. NodD1 and NodW are both required for efficient transcription of the nod box-regulated nodABC gene cluster (Göttfert et al. 1990, 1992; Loh et al. 1997, 2001).

Addition of genistein to the culture medium led to an induction of $i d 205$, nolU, nopL, rhcV, and ttsI in the wild-type back- ground (Fig. 3). None of the genes was induced in the nodW and nodD1nodD2nolA mutants. Furthermore, expression of id205, nolU, nopL, and $r h c V$ is strictly dependent on TtsI. In contrast, the expression level of $r h c C 1$ was not enhanced by genistein and was independent of the transcriptional activators NodW and TtsI as well as the nodD1nodD2nolA gene region.

It was demonstrated previously that NodD1 activates nod box-controlled nodulation genes (Banfalvi et al. 1988; Göttfert et al. 1992). In order to verify that NodD1 is also required for flavonoid-dependent induction of ttsI and nolU, mutant strains containing the corresponding lac $Z$ fusions in the nodD1nodD2nolA background were complemented with a

Table 1. Acetylene reduction per nodule 28 days after inoculation, shown in percent of wild-type activity ${ }^{\mathrm{a}}$

\begin{tabular}{lccrrrrr}
\hline Plant/Strain & Wild type & \multicolumn{1}{c}{$\Delta \mathbf{1 2 1}$} & \multicolumn{1}{c}{$\Delta \mathbf{1 2 2}$} & \multicolumn{1}{c}{$\Delta \mathbf{1 3 2}$} & \multicolumn{1}{c}{$\Delta \mathbf{1 3 6}$} & \multicolumn{1}{c}{$\Delta \mathbf{1 3 9}$} & \multicolumn{1}{c}{$\Delta \mathbf{1 7 1}$} \\
\hline Glycine max & $100 \pm 31.0$ & $59.0 \pm 6.9$ & $64.1 \pm 18.8$ & $55.2 \pm 12.3$ & $63.0 \pm 19.9$ & $71.9 \pm 17.7$ & $102.1 \pm 21.8$ \\
Macroptilium atropurpureum & $100 \pm 35.8$ & $232.7 \pm 96.3$ & $265.7 \pm 95.1$ & $209.6 \pm 50.9$ & $243.0 \pm 51.0$ & $153.8 \pm 59.0$ & $269.1 \pm 88.8$ \\
Vigna unguiculata & $100 \pm 34.9$ & $106.5 \pm 25.7$ & $106.7 \pm 66.3$ & $70.6 \pm 59.2$ & $76.8 \pm 13.9$ & $59.9 \pm 21.5$ & $145.7 \pm 48.6$ \\
\hline
\end{tabular}

${ }^{a}$ Values (average \pm standard deviation) are calculated from five plants per strain. The actual ethylene peak areas for the wild-type strain on $G$. max, $M$. atropurpureum, and V. unguiculata are 9682.9, 6097.9, and 2725.2, respectively.
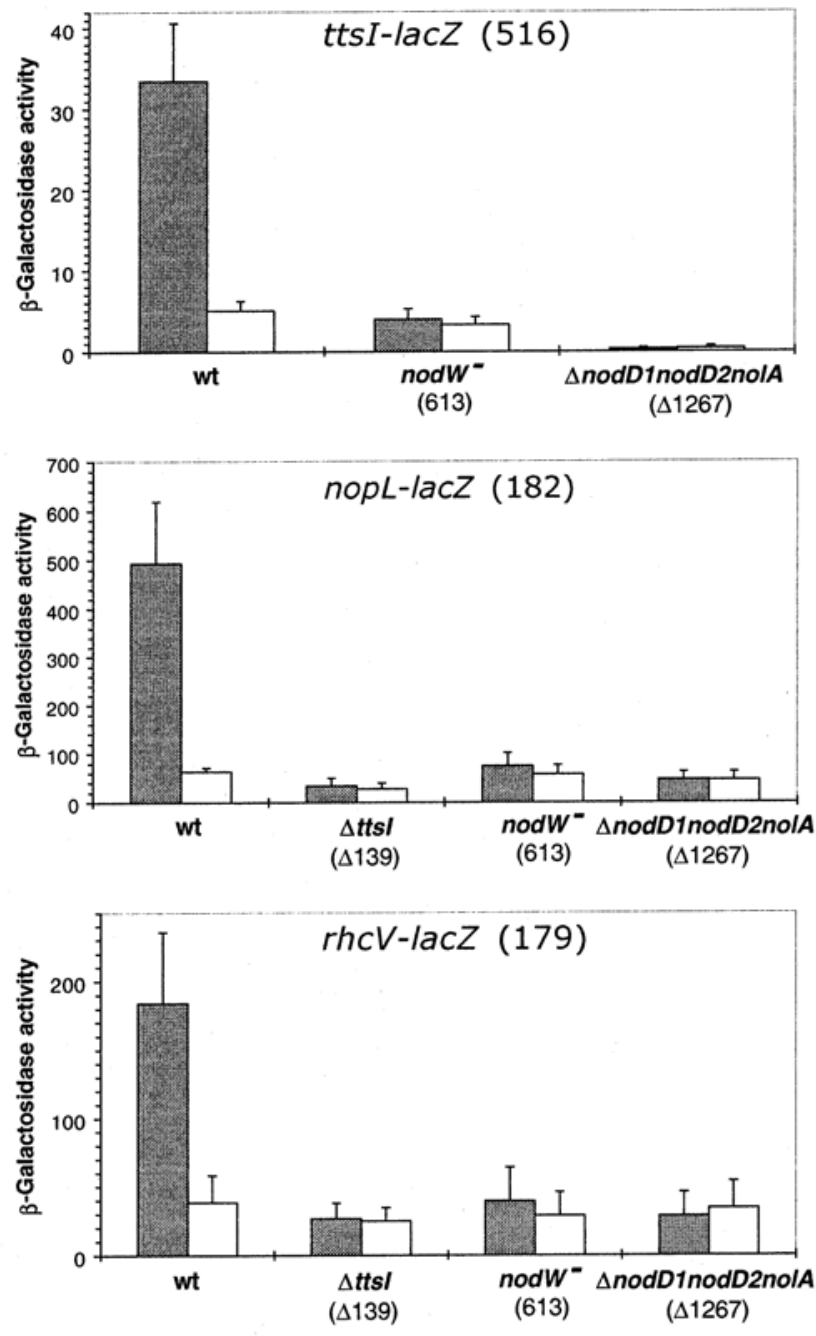
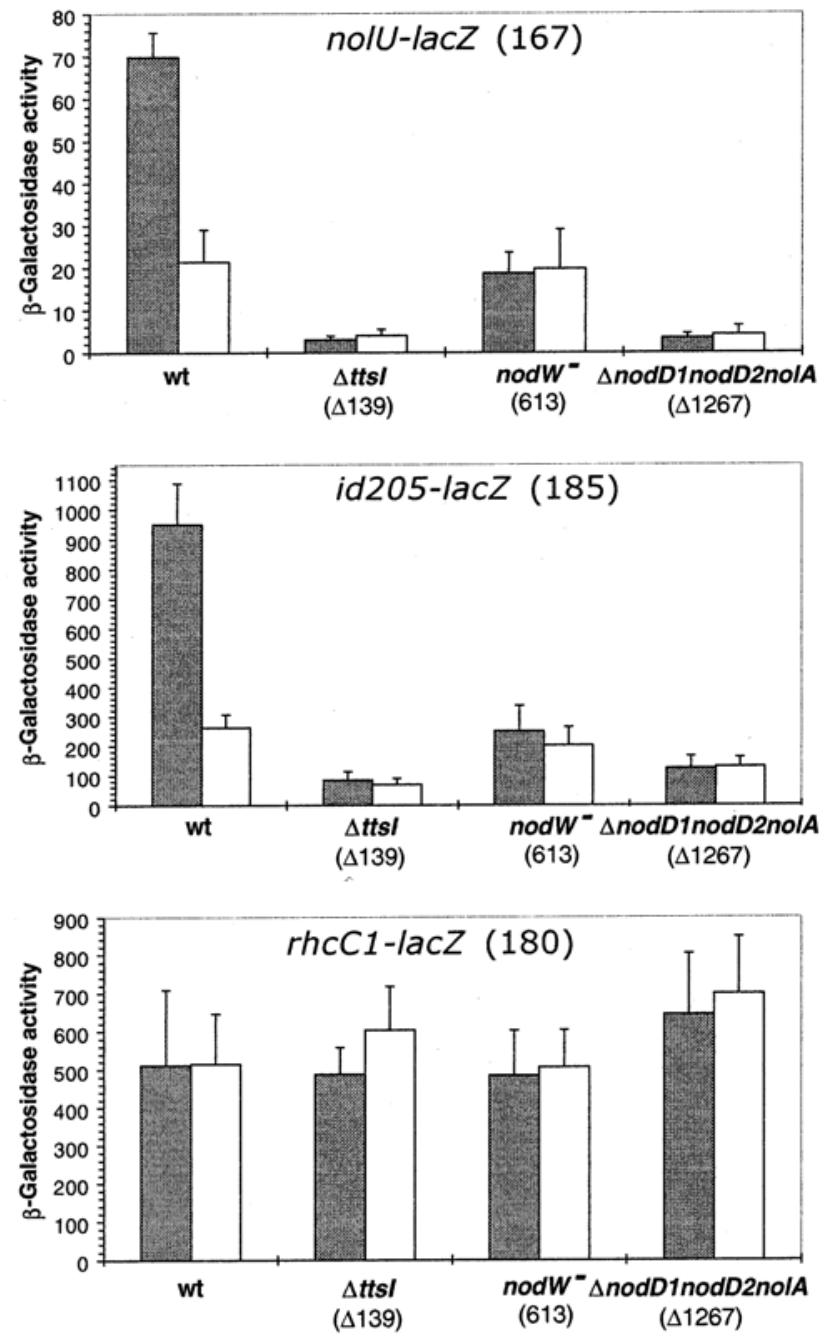

+ Genistein - Genistein

Fig. 3. Expression analyses of the $t$ ts gene cluster. $\beta$-Galactosidase activity was determined $24 \mathrm{~h}$ after induction for strains carrying the $t$ ts $I$ - and $r h c C 1$ lacZ fusions and $48 \mathrm{~h}$ after induction for the other strains. Activities are given in pmol MU per $\mu \mathrm{g}$ of protein per min of reaction time. Values (average \pm standard deviation) are determined from at least five independent cultures measured in duplicate. 
broad host range plasmid carrying nodDl (pRJ420). Figure 4 shows that nodDl is sufficient for restoring inducibility.

\section{The putative promoter regions}

within the $t$ ts gene cluster contain a conserved element.

To identify potential promoter elements, we aligned putative promoter regions with corresponding sequences of the $t$ ts gene clusters of NGR234, M. loti, and S. fredii (Fig. 5). This analysis revealed a conserved sequence motif, for which we suggest the designation $t t s$ box. In the case of the $S$. fredii nolB and nolX genes, the conserved region is located 10 and $11 \mathrm{bp}$ upstream of the transcriptional start site (Kovács et al. 1995). Thus, it is highly likely that the tts box is part of the promoter. Based on the sequence analysis and the results obtained from expression analyses (Figs. 3 and 4), we propose a regulatory cascade for the activation of the $t t s$ gene cluster that is depicted in Figure 6.

\section{DISCUSSION}

Here, we have shown that the expression of ttsI, which is preceded by a nod box, is inducible by genistein. NodW and

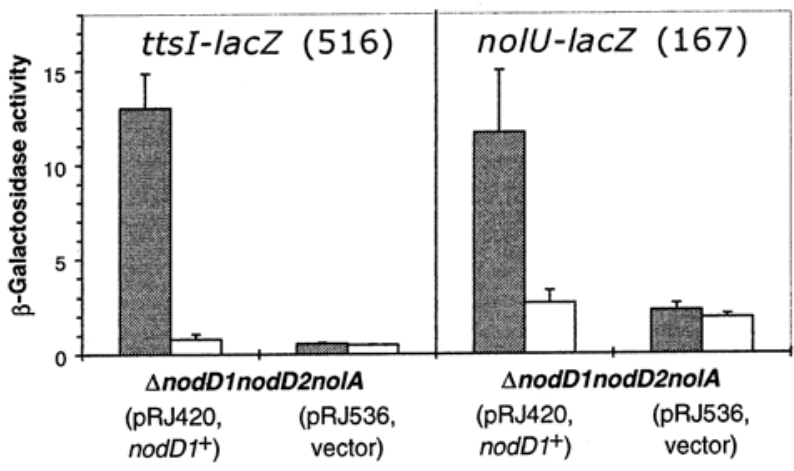

+ Genistein - Genistein

Fig. 4. Activation of $t t s I$ and nol $U$ gene expression by NodD1. $\beta$-Galactosidase activity was determined $48 \mathrm{~h}$ after induction. Activities are given in pmol MU per $\mu \mathrm{g}$ of protein per min of reaction time. Values (average \pm standard deviation) are determined from four independent cultures measured in duplicate. one or more proteins encoded by the nodDlnodD2nolA region are required for induction. Our data indicate that the likely regulatory candidate of the $\operatorname{nodD}$ region is NodD1, which is already known to activate nod box-controlled nodulation genes.

Surprisingly, id205, nolU, nopL, and rhcV, which have no nod box promoter, are also regulated by $\operatorname{nod} W$ and the nodD gene region in a flavonoid-dependent manner (Fig. 3). In addition, $t t s I$ is essential for the activation of all of these genes. Therefore, we postulate that TtsI, which-based on sequence similarity-belongs to the two-component regulatory family, is the direct activator of the $t$ ts gene cluster (Fig. 6). Common to the investigated operons is the presence of a tts box sequence within the putative promoter regions (Fig. 5). The same element is also conserved in tts clusters of other rhizobia. In the case of nolB and nolX of $S$. fredii, the tts box is located 10 and $11 \mathrm{bp}$ upstream of the transcriptional start site (Kovács et al. 1995). Moreover, a deletion that extends into the $t t s$ box of nolB from $S$. fredii abolishes promoter activity $(\mathrm{Gu}$ et al. 1997). Thus, it is highly likely that the $t t s$ box is a central component of the promoter. Further analyses of the $t t s$ box are in progress to confirm this.

Interestingly, $r h c C 1$, which is transcribed divergently from nolU, seems to be constitutively expressed (Fig. 3). Constitutive expression was also reported for the homologue in $S$. fredii (Kovács et al. 1995, there called nolW). According to Viprey and associates (1998), the protein is part of the transport complex of the TTSS and is located in the outer membrane. The different expression pattern suggests that the protein might have an additional, still unknown, function.

Mutations within the tts gene cluster of B. japonicum affected symbiosis in a host-dependent manner. Similar observations have been reported for S. fredii (Bellato et al. 1997; Meinhardt et al. 1993) and Rhizobium strain NGR234 (Viprey et al. 1998). This host-specific effect may be due to differences in $t$ ts gene expression in the various hosts or due to differences in reaction of the hosts to the putatively secreted proteins.

One of the most important questions is about the nature and function of the secreted proteins. Rhizobium strain NGR234 transports at least eight proteins in a TTSS-dependent manner (Marie et al. 2001). The only two identified proteins are NopX and NopL; however, their function is unknown (Viprey et al. 1998). S. fredii appears to be similar (Krishnan et al. 1995). Based on Southern hybridization, B. japonicum does not seem to contain nopX (data not shown). However, it contains an ORF with similarity to nopL and several ORFs outside the $t$ ts gene

\begin{tabular}{|c|c|c|c|c|c|}
\hline Bjap & rhacl & $90 \mathrm{bp}$ & . TCCGTCAGGTTTTCGTCAGCTCGGCAGCCTA & $61 \mathrm{bp}$ & nolB \\
\hline M. Ioti & $\operatorname{ml16338}$ & $120 \mathrm{bp}$ & . TCAGTCAGCTTGTCGTCAGCTCGGCCACCTA & 71 bp & $m \operatorname{lr} 8763$ \\
\hline NGR234 & rhcc1 & 85 & . GTAGTCAGCGTGTCGTCAGCTCGCCTCGCTA & 39 bp & nolB \\
\hline Sf 257 & $\mathrm{nolW}$ & $85 \mathrm{bp}$ & . GTAGTCAGCGTGTCGTCAGCTCGCCTCGCTA & 39 bp & $11 \mathrm{bp}$ to +1 \\
\hline Bjap & & & ATCATCGTCAGCTTTTCGACAGGTGTTCGGGCTA & $-221 \mathrm{bp}$ & id 205 \\
\hline NGR2 34 & & & ACAATTGTCAGCTTTTCGAAAGCTGGAGCTCATA & $-410 \mathrm{bp}$ & orf \\
\hline Bjap & & & AGGCTCGTCAGCTTTTCGAAAGCTAGCGCCCCTA & $-415 \mathrm{bp}$ & поpA \\
\hline Bjap & & & CCGATCGTCAGCTTTTCGAAAGCTAAAGCCCCCA & $-208 \mathrm{bp}$ & nopL \\
\hline GR23 4 & & & AGCCTCGTCAGTTTCTCGAAAGCTAAACCGCTCA & $-188 \mathrm{bp}$ & nopX \\
\hline Sf 257 & & & AGCCTCGTCAGTTTCTCGAAAGCTAAACCGCTCA & $-189 \mathrm{bp}$ & nolx 10 bp to +1 \\
\hline M. Ioti & & & GAACTCGTCAGTTTACCGAAAGCTAAACCGCTCA & $-100 \mathrm{bp}$ & $\operatorname{mII6337}$ \\
\hline M. Ioti & & & AGACTCGTCAGGTTCTCGAAAGCTCCTGCTCGTA & $-446 \mathrm{bp}$ & orf \\
\hline NGR2 34 & & & CTGATTGTCAGCTTCTCGAAAGGTATGTCTCTTA & $82 \mathrm{bp}$ & nopL \\
\hline Bjap & & & GCGAT-GTCAGGTTTTGGAAAGCAAACGTGAGTA & $36 \mathrm{bp}$ & $i d 274$ \\
\hline
\end{tabular}

Fig. 5. Comparison of putative promoter regions within tts gene clusters. Numbers indicate distances in bp between the tts box and the assumed translational start site of the corresponding open reading frame. For nolX and nolB from Sinorhizobium fredii, the distance between the conserved sequence and the transcriptional start site is indicated in bp at the end of the lines. In the consensus sequence, all invariant nucleotides are shown in capital letters. Lower case letters are used for nucleotides conserved in at least 50\% of the sequences. Bjap = Bradyrhizobium japonicum; M. loti $=$ Mesorhizobium loti MAFF303099; NGR234 = Rhizobium strain NGR234; and Sf257 = S. fredii USDA257. 
cluster whose products are similar to type III secreted proteins from pathogens (Göttfert et al. 2001). Moreover, there are several ORFs located within the tts gene cluster that currently do not match database entries. All these ORFs are candidates for encoding proteins transported by the TTSS. Our current effort is directed towards the identification of secreted proteins as the next step for the analysis of protein function.

\section{MATERIALS AND METHODS}

\section{Bacterial strains and growth conditions.}

Bacterial strains used in this study are listed in Table 2. Escherichia coli strains were grown in Luria-Bertani (LB) medium (Sambrook et al. 1989) with appropriate antibiotics added.

B. japonicum strains were cultivated at $28^{\circ} \mathrm{C}$ in peptonesalts-yeast extract (PSY) medium (Regensburger and Hennecke 1983), AG (arabinose-gluconate) medium (Sadowsky et al. 1987) or yeast extract-mannitol (YEM) medium (Daniel and Appleby 1972). PSY was used for bacterial crosses with E. coli, AG medium for routine cultures, and YEM medium for $\beta$-galactosidase activity assays. Antibiotics were used at a final concentration of $100 \mu \mathrm{g}$ per $\mathrm{ml}$.

\section{Bacterial crosses.}

E. coli S17-1 containing recombinant pSUPPOL2SCA derivatives and $B$. japonicum strains were grown to stationary phase in LB or PSY, respectively, with appropriate antibiotics

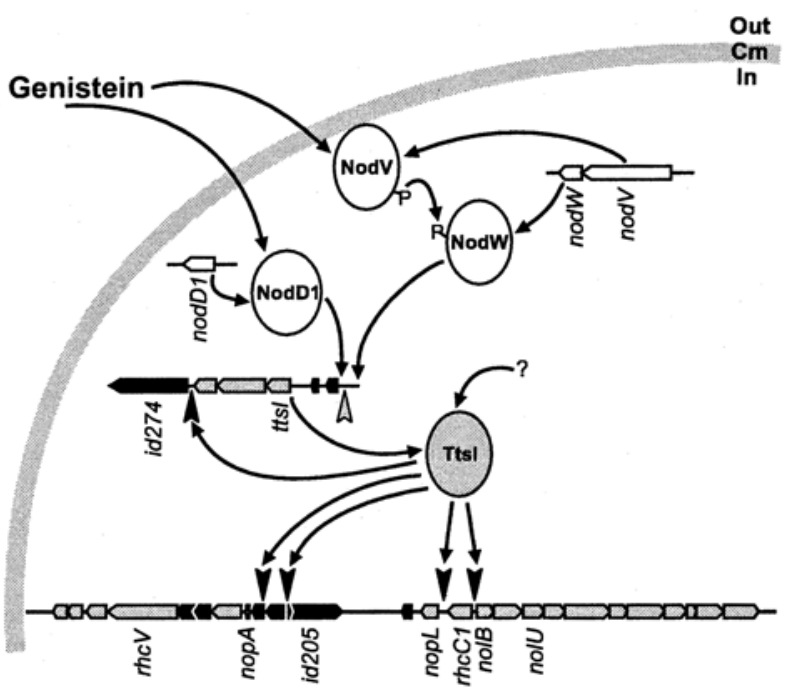

Fig. 6. Model of the regulatory cascade controlling expression of the tts gene cluster. Open reading frames (ORFs) unique to Bradyrhizobium japonicum are in black, and nod genes are shown in white. ORFs with homologues in tts gene clusters of other rhizobia are gray. ORFs related to IS elements are not shown. The gray arrowhead indicates the position of the nod box. Positions of tts boxes are marked by black arrowheads. $\mathrm{Cm}=$ cytoplasmic membrane.

Table 2. Bacterial strains used in this study

\begin{tabular}{|c|c|c|}
\hline Strain & Relevant characteristics $^{\mathrm{a}}$ & Source or reference \\
\hline \multicolumn{3}{|c|}{ Bradyrhizobium japonicum } \\
\hline $110 \operatorname{spc} 4$ & referred to as wild type, $\mathrm{Sp}^{\mathrm{r}}$ & Regensburger and Hennecke 1983 \\
\hline 613 & $n o d W:: \Omega, \mathrm{Sm}^{\mathrm{r}} \mathrm{Sp}^{\mathrm{r}}$ & Göttfert et al. 1990 \\
\hline$\Delta 1267$ & $\Delta$ (ORF3 ORF2 nolA nodD2 nodD1), $\mathrm{Km}^{\mathrm{r}} \mathrm{Sp}^{\mathrm{r}}$ & Göttfert et al. 1992 \\
\hline$\Delta 121$ & $\Delta\left(r h c N^{\mathrm{b}}\right.$ y4yJ rhcQ $\left.r h c R^{\mathrm{b}}\right), \mathrm{Km}^{\mathrm{r}} \mathrm{Sp}^{\mathrm{r}}$ & This work \\
\hline$\Delta 122$ & $\Delta\left(\right.$ rhc V $V^{\mathrm{b}}$ id192 id193 y4yQ nopA id $\left.202^{\mathrm{b}}\right), \mathrm{Km}^{\mathrm{r}} \mathrm{Sp}^{\mathrm{r}}$ & This work \\
\hline$\Delta 132$ & $\Delta$ (nolB rhcJ nolU nolV rhcN $N^{\mathrm{b}}, \mathrm{Km}^{\mathrm{r}} \mathrm{Sp}^{\mathrm{r}}$ & This work \\
\hline$\Delta 136$ & $\Delta\left(i d 274^{\mathrm{b}}\right.$ y4xK rhcC2 ttsI id287 id289 id293), $\mathrm{Km}^{\mathrm{r}} \mathrm{Sp}^{\mathrm{r}}$ & This work \\
\hline$\Delta 139$ & $\Delta t t s I, \mathrm{Km}^{\mathrm{r}} \mathrm{Sp}^{\mathrm{r}}$ & This work \\
\hline$\Delta 171$ & $\Delta r h c C l, \mathrm{Km}^{\mathrm{r}} \mathrm{Sp}^{\mathrm{r}}$ & This work \\
\hline wt-167 & nolU-lacZ integrated into the wild-type background, $\mathrm{Sp}^{\mathrm{r}} \mathrm{Tc}^{\mathrm{r}}$ & This work \\
\hline$\Delta 139-167$ & nolU-lacZ integrated into the $t$ tsI deletion derivative $\Delta 139, \mathrm{Km}^{\mathrm{r}} \mathrm{Sp}^{\mathrm{r}} \mathrm{Tc}^{\mathrm{r}}$ & This work \\
\hline $613-167$ & nolU-lacZ integrated into the nodW mutant strain $613, \mathrm{Sm}^{\mathrm{r}} \mathrm{Sp}^{\mathrm{r}} \mathrm{Tc}^{\mathrm{r}}$ & This work \\
\hline$\Delta 1267-167$ & nolU-lacZ integrated into the nodD2nodD1nolA mutant derivative $\Delta 1267, \mathrm{Km}^{\mathrm{r}} \mathrm{Sp}^{\mathrm{r}} \mathrm{Tc}^{\mathrm{r}}$ & This work \\
\hline wt-179 & $r h c V$-lacZ integrated into the wild-type background, $\mathrm{Sp}^{\mathrm{r}} \mathrm{Tc}^{\mathrm{r}}$ & This work \\
\hline$\Delta 139-179$ & rhcV-lacZ integrated into the ttsI deletion derivative $\Delta 139, \mathrm{Km}^{\mathrm{r}} \mathrm{Sp}^{\mathrm{r}} \mathrm{Tc}^{\mathrm{r}}$ & This work \\
\hline $613-179$ & rhcV-lacZ integrated into the nodW mutant strain $613, \mathrm{Sm}^{\mathrm{r}} \mathrm{Sp}^{\mathrm{r}} \mathrm{Tc}^{\mathrm{r}}$ & This work \\
\hline$\Delta 1267-179$ & $r h c V$-lacZ integrated into the nodD2nodD1nolA mutant derivative $\Delta 1267, \mathrm{Km}^{\mathrm{r}} \mathrm{Sp}^{\mathrm{r}} \mathrm{Tc}^{\mathrm{r}}$ & This work \\
\hline wt-180 & rhcC1-lacZ integrated into the wild-type background, $\mathrm{Sp}^{\mathrm{r}} \mathrm{Tc}^{\mathrm{r}}$ & This work \\
\hline$\Delta 139-180$ & rhcCl-lacZ integrated into the $t t s I$ deletion derivative $\Delta 139, \mathrm{Km}^{\mathrm{r}} \mathrm{Sp}^{\mathrm{r}} \mathrm{Tc}^{\mathrm{r}}$ & This work \\
\hline $613-180$ & rhcC1-lacZ integrated into the nodW mutant strain $613, \mathrm{Sm}^{\mathrm{r}} \mathrm{Sp}^{\mathrm{r}} \mathrm{Tc}^{\mathrm{r}}$ & This work \\
\hline$\Delta 1267-180$ & rhcC1-lacZ integrated into the nodD2nodD1nolA mutant derivative $\Delta 1267, \mathrm{Km}^{\mathrm{r}} \mathrm{Sp}^{\mathrm{r}} \mathrm{Tc}^{\mathrm{r}}$ & This work \\
\hline wt-182 & nopL-lacZ integrated into the wild-type background, $\mathrm{Sp}^{\mathrm{r}} \mathrm{Tc}^{\mathrm{r}}$ & This work \\
\hline$\Delta 139-182$ & nopL-lacZ integrated into the ttsI deletion derivative $\Delta 139, \mathrm{Km}^{\mathrm{r}} \mathrm{Sp}^{\mathrm{r}} \mathrm{Tc}^{\mathrm{r}}$ & This work \\
\hline $613-182$ & nopL-lac $Z$ integrated into the nodW mutant strain $613, \mathrm{Sm}^{\mathrm{r}} \mathrm{Sp}^{\mathrm{r}} \mathrm{Tc}^{\mathrm{r}}$ & This work \\
\hline$\Delta 1267-182$ & nopL-lacZ integrated into the nodD2nodD1nolA mutant derivative $\Delta 1267, \mathrm{Km}^{\mathrm{r}} \mathrm{Sp}^{\mathrm{r}} \mathrm{Tc}^{\mathrm{r}}$ & This work \\
\hline wt-185 & id205-lacZ integrated into the wild-type background, $\mathrm{Sp}^{\mathrm{r}} \mathrm{Tc}^{\mathrm{r}}$ & This work \\
\hline$\Delta 139-185$ & id205-lacZ integrated into the $t t s I$ deletion derivative $\Delta 139, \mathrm{Km}^{\mathrm{r}} \mathrm{Sp}^{\mathrm{r}} \mathrm{Tc}^{\mathrm{r}}$ & This work \\
\hline $613-185$ & id205-lacZ integrated into the nodW mutant strain $613, \mathrm{Sm}^{\mathrm{r}} \mathrm{Sp}^{\mathrm{r}} \mathrm{Tc}^{\mathrm{r}}$ & This work \\
\hline$\Delta 1267-185$ & id205-lacZ integrated into the nodD2nodD1nolA mutant derivative $\Delta 1267, \mathrm{Km}^{\mathrm{r}} \mathrm{Sp}^{\mathrm{r}} \mathrm{Tc}^{\mathrm{r}}$ & This work \\
\hline wt-516 & ttsI-lacZ integrated into the wild-type background, $\mathrm{Sp}^{\mathrm{r}} \mathrm{Tc}^{\mathrm{r}}$ & This work \\
\hline $613-516$ & ttsI-lacZ integrated into the nodW mutant strain $613, \mathrm{Sm}^{\mathrm{r}} \mathrm{Sp}^{\mathrm{r}} \mathrm{Tc}^{\mathrm{r}}$ & This work \\
\hline$\Delta 1267-516$ & ttsI-lacZ integrated into the nodD2nodD1nolA mutant derivative $\Delta 1267, \mathrm{Km}^{\mathrm{r}} \mathrm{Sp}^{\mathrm{r}} \mathrm{Tc}^{\mathrm{r}}$ & This work \\
\hline \multicolumn{3}{|c|}{ 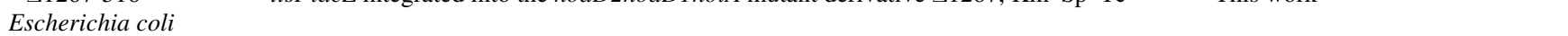 } \\
\hline XL1-Blue & 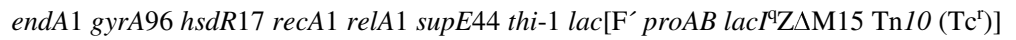 & Bullock et al. 1987 \\
\hline RR28 & hsdR hsdM recA pheS12 thi leu pro lac gal ara mtl 1 xyl5 supE 44 endA, $\mathrm{Sm}^{\mathrm{r}}$ & Hennecke et al. 1982 \\
\hline $\mathrm{S} 17-1$ & $h s d R$ pro thi (RP4-2 km::Tn7 tc::Mu, integrated into the chromosome), $\mathrm{Sm}^{\mathrm{r}} \mathrm{Sp}^{\mathrm{r}}$ & Simon et al. 1983 \\
\hline
\end{tabular}

${ }^{\mathrm{a}} \mathrm{Ap}=$ ampicillin; $\mathrm{Km}=$ kanamycin; $\mathrm{Sm}=$ streptomycin; $\mathrm{Sp}=$ spectinomycin; and $\mathrm{Tc}=$ tetracycline.

${ }^{\mathrm{b}}$ The corresponding open reading frame (ORF) is not completely deleted from the genome. 
added. Bacteria from $1 \mathrm{ml}$ of each culture were pelleted, were resuspended in $1 \mathrm{ml}$ (E. coli) or $0.1 \mathrm{ml}$ (B. japonicum) $0.9 \%$ $\mathrm{NaCl}$, and were mixed at a volume ratio of 1:5. The mixture $(80 \mu \mathrm{l})$ was placed as a drop on PSY solid medium and was incubated for 3 days at $30^{\circ} \mathrm{C}$. The cells were harvested, were resuspended in $1 \mathrm{ml}$ of $0.9 \% \mathrm{NaCl}$, and were plated on selective PSY solid media. Broad host range plasmids pRJ420 and pRJ536 were mobilized into B. japonicum by triparental mating. Strains were grown, pelleted, and resuspended as described above. Donor, helper, and recipient were mixed at a volume ratio of $1: 1.5: 1.5$. The mixture was treated as described.

\section{DNA protocols and sequence data analysis.}

Recombinant DNA techniques were performed following established protocols as compiled by Sambrook and associates (1989). Blast similarity searches were done at the National Center for Biotechnology Information website. The program FastA of the GCG software package (Accelrys Inc., Cambridge, U.K.) was used for the identification of the $t t s$ box sequences. Alignments were done with MultAlin at the INRA website. (Published research using this software should cite: "Multiple sequence alignment with hierarchical clustering" F. CORPET, 1988, Nucl. Acids Res., 16 (22), 10881-10890)

\section{Generation of mutations in the tts gene cluster.}

Detailed information about strains and plasmids is given in Tables 2 and 3. In summary, gene regions were cloned into suitable vectors. DNA segments to be deleted were replaced by a $\mathrm{Km}^{\mathrm{r}}$ cassette. The modified fragments were recloned into the mobilizable vector pSUPPOL2SCA. The resulting plasmids were transformed into $E$. coli $\mathrm{S} 17-1$ and were mobilized into $B$. japonicum wild type. Double-crossover events at homologous sites resulted in kanamycin-resistant strains. Correct recombinants were confirmed by polymerase chain reaction (PCR) and Southern blot analyses.

\section{Construction and chromosomal integration of translational lac Z fusions.}

Strains and vectors are listed in Tables 2 and 3. Appropriate parts of id205, nolU, nopL, rhcC1, rhcV, and ttsI were cloned into the lacZ fusion vectors $\mathrm{pNM} 480 \mathrm{X}$, pNM481X, or pNM482N. Because RhcC1 and RhcV are predicted to be membrane proteins, $l a c Z$ was fused directly to the first triplet.
Similarly, lacZ was fused to the first codon of id205 and to the second codon of nopL, because both genes might encode secreted proteins. The correct fusion sites were confirmed by DNA sequencing. The fusions were recloned into the mobilizable vector $\mathrm{pSUPPOL2SCA}$. The recombinant plasmids were transformed into $E$. coli strain S17-1 and were mobilized into $B$. japonicum wild type as well as mutant derivatives. The vector-encoded $\mathrm{Tc}^{\mathrm{r}}$ marker allowed the selection of strains with plasmids integrated into the chromosome. The correct integration event was confirmed by PCR and Southern blot analysis.

\section{Plant infection tests.}

Plants used in this study are listed in Table 4. Seeds were surface-sterilized as described by Krause and Broughton (1992) and were germinated at room temperature for 2 to 3 days on water agar. B. japonicum strains were grown in PSY at $28^{\circ} \mathrm{C}$ to late logarithmic phase, were pelleted, and were resuspended in $\mathrm{H}_{2} \mathrm{O}$ to an optical density at $600 \mathrm{~nm}$ of 0.4 . Germinated seeds were transferred to Magenta GA7 vessels (Invitrogen Corp., San Diego, CA, U.S.A.) filled with vermiculite (2to 3-mm particle size), and $200 \mathrm{ml} 0.5 \times$ nitrogen-free Jensen medium (Vincent, 1970). Each seedling was inoculated with $0.4 \mathrm{ml}$ of the bacterial suspension. Plants were cultivated in a growth chamber (Sanyo MRL-350; Sanyo Electric Co., Moriguchi City, Osaka, Japan) with a daytime of $16 \mathrm{~h}, 26^{\circ} \mathrm{C}$, and light intensity of $370 \mu \mathrm{mol} / \mathrm{sec} / \mathrm{m}^{2}$, followed by a nighttime of $8 \mathrm{~h}$ and $22^{\circ} \mathrm{C}$. To determine the number of root nodules, plants were harvested 10 and 20 days after inoculation.

\section{Acetylene reduction assays.}

Acetylene reduction of whole root systems was measured 28 days after inoculation, essentially using the method of Somasegaran and Hoben (1994). Each root was placed in a 100-ml rubber-stopped flask for G. max and V. unguiculata or a

Table 4. Legume species used in this study

\begin{tabular}{lll}
\hline Plant & \multicolumn{1}{c}{ Cultivar } & \multicolumn{1}{c}{ Seed source } \\
\hline Glycine max (L.) Merr. & Williams & $\begin{array}{l}\text { P. Gresshoff, University of } \\
\text { Queensland, Australia }\end{array}$ \\
$\begin{array}{l}\text { Macroptilium } \\
\text { atropurpureum (Moç \& }\end{array}$ & Siratro & $\begin{array}{l}\text { Wrightson Seeds } \\
\text { Sessé ex DC.) Urb. }\end{array}$ \\
$\begin{array}{l}\text { Vigna unguiculata } \\
\text { (L.) Walp. }\end{array}$ & Red Caloona Hills, Australia) & $\begin{array}{l}\text { Wrightson Seeds } \\
\text { (Seven Hills, Australia) }\end{array}$ \\
\hline
\end{tabular}

Table 3. Plasmids and cosmids used in this study

\begin{tabular}{|c|c|c|}
\hline Cosmid/plasmid & Relevant characteristics $^{\mathrm{a}}$ & Source or reference \\
\hline \multicolumn{3}{|l|}{ Cosmid } \\
\hline 46-B6 & Chromosomal fragment of Bradyrhizobium japonicum in Lorist6, $\mathrm{Km}^{\mathrm{r}}$ & Kündig 1994 \\
\hline 57-D12 & Chromosomal fragment of B. japonicum in Lorist6, $\mathrm{Km}^{\mathrm{r}}$ & Kündig 1994 \\
\hline \multicolumn{3}{|c|}{ (1) } \\
\hline pBluescript II SK (+) & Cloning vector, $\mathrm{Ap}^{\mathrm{r}}$ & Stratagene, La Jolla, CA, U.S.A. \\
\hline pNM480X & Derivative of pNM480 (Minton 1984) with a XbaI restriction site instead of a StuI site, Ap ${ }^{\mathrm{r}}$ & Göttfert et al. 1992 \\
\hline pNM481X & Derivative of pNM481 (Minton 1984) with a XbaI restriction site instead of a StuI site, $\mathrm{Ap}^{\mathrm{r}}$ & Göttfert et al. 1992 \\
\hline pNM482N & Derivative of pNM481 (Minton 1984) with a NheI restriction site instead of a StuI site, Ap ${ }^{\mathrm{r}}$ & A. Krause, unpublished data \\
\hline pRJ420 & $\begin{array}{l}\text { Broad host range plasmid containing nodD1 and a streptomycin/spectinomycin resistance } \\
\text { marker, } \mathrm{Sm}^{\mathrm{r}} \mathrm{Sp}^{\mathrm{r}} \mathrm{Tc}^{\mathrm{r}}\end{array}$ & M. Göttfert, unpublished data \\
\hline pRJ536 & $\begin{array}{l}\text { Broad host range plasmid containing a streptomycin/spectinomycin resistance marker, } \mathrm{Sm}^{\mathrm{r}} \\
\mathrm{Sp}^{\mathrm{r}} \mathrm{Tc}^{\mathrm{r}}\end{array}$ & M. Göttfert, unpublished data \\
\hline pRK2013 & $\operatorname{tra}^{+}, \mathrm{Km}^{\mathrm{r}}$ & Figurski and Helinski 1979 \\
\hline pSUPPOL2SCA & $\begin{array}{l}\text { Derivative of pSUP202 (Simon et al. 1983) with a polylinker in the PstI site that reads } \\
\text { SacII-XmaIII-NotI-XbaI-SpeI-BamHI-SmaI-PstI-EcoRI-EcoRV-HindIII-ClaI-SalI-XhoI- } \\
\text { DraII [derived from pBluescript II SK (+)], deletion of the } 1.3 \text {-kb fragment encompassing } \\
\text { the chloramphenicol resistance gene, oriT of RP4, Tc }{ }^{\mathrm{r}}\end{array}$ & A. Krause, unpublished data \\
\hline pUC-4-KIXX & Source of the $\mathrm{Km}^{\mathrm{r}}$ cassette, $\mathrm{Ap}^{\mathrm{r}} \mathrm{Km}^{\mathrm{r}}$ & Pharmacia, Uppsala, Sweden \\
\hline pUC9 & Cloning vector, $\mathrm{Ap}^{\mathrm{r}}$ & Norrander et al. 1983 \\
\hline pUC18 & Cloning vector, $\mathrm{Ap}^{\mathrm{r}}$ & Norrander et al. 1983 \\
\hline
\end{tabular}

\footnotetext{
${ }^{\mathrm{a}} \mathrm{Ap}=$ ampicillin $; \mathrm{Km}=$ kanamycin $; \mathrm{Sm}=$ streptomycin $; \mathrm{Sp}=$ spectinomycin and $\mathrm{Tc}=$ tetracycline .
} 
15-ml rubber-stopped glass tube for $M$. atropurpureum. Ten percent of the air was replaced by acetylene 2.6 (MesserGriesheim, Ottendorf-Okrilla, Germany). After $1.5 \mathrm{~h}$ incubation at $30^{\circ} \mathrm{C}, 0.5 \mathrm{ml}$ of the gas phase was injected into a gas chromatograph (GC 17A; Shimadzu Europe, Duisburg, Germany) stainless steel column $6 \mathrm{ft} \times 1 / 8 \mathrm{in} . \times 2 \mathrm{~mm}$ packed with Porapak N, 100/200 mesh size (Machery-Nagel, Düren, Germany). Acetylene reduction per nodule was calculated as peak area ethylene per nodule. The peak area of ethylene was corrected by the area of the ethylene peak found in the acetylene control. The values of the wild-type strain on G. $\max , M$. atropurpureum, and V. unguiculata were set to $100 \%$.

\section{Determination of $\beta$-galactosidase activity.}

Cultures were grown in selective YEM medium for 4 days at $28^{\circ} \mathrm{C}$. Cells were collected by centrifugation and were resuspended in half volume fresh selective YEM medium. Genistein dissolved in methanol was added to a final concentration of 1 $\mu \mathrm{M}$. Controls received methanol only. After an additional incubation for 24 to $48 \mathrm{~h}$ at $28^{\circ} \mathrm{C}$, two $1-\mathrm{ml}$ samples were taken. Cells were pelleted, were washed with $\mathrm{RC}$ buffer $(25 \mathrm{mM}$ Tris $\mathrm{HCl} \mathrm{pH} 7.5,125 \mathrm{mM} \mathrm{NaCl}, 2 \mathrm{mM} \mathrm{MgCl} \mathrm{M}_{2} \times 6 \mathrm{H}_{2} \mathrm{O}, 12 \mathrm{mM} \beta-$ mercaptoethanol), and were resuspended in $200 \mu \mathrm{RC}$ buffer. To permeabilize the cells, $20 \mu \mathrm{l}$ chloroform and $20 \mu \mathrm{l}$ sodium dodecyl sulfate $(0.1 \%)$ were added. This cell suspension (40 $\mu \mathrm{l})$ was mixed with $160 \mu \mathrm{l}$ of RC buffer containing 4-methylumbelliferyl- $\beta$-D-galactopyranosid $(300 \mu \mathrm{M})$. Reactions were incubated for $2 \mathrm{~h}$ at $30^{\circ} \mathrm{C}$ and were terminated by the addition of $50 \mu \mathrm{l}$ of trichloroacetic acid (25\%). Reaction mixture (100 $\mu \mathrm{l})$ was added to $1.9 \mathrm{ml} \mathrm{GC}$ buffer $(133 \mathrm{mM}$ glycine, $83 \mathrm{mM}$ $\mathrm{Na}_{2} \mathrm{CO}_{3}, \mathrm{pH}$ 10.7). Fluorescence of the reaction product 4-methylumbelliferone (MU) was measured with a fluorometer (VersaFluor Fluorometer, Bio-Rad Laboratories, Hercules, CA, U.S.A.) by excitation at $365 \mathrm{~nm}$ and by emission at $455 \mathrm{~nm}$. $\beta$ Galactosidase activity was calculated as pmol MU per $\mu \mathrm{g}$ of protein per min reaction time.

Permeabilized cells $40(\mu \mathrm{l})$ were used to determine protein concentrations using the Bio-Rad protein assay (Bio-Rad Laboratories).

\section{ACKNOWLEDGMENTS}

We are grateful to M. Weishaupt for technical assistance.

\section{LITERATURE CITED}

Banfalvi, Z., Nieuwkoop, A., Schell, M., Besl, L., and Stacey, G. 1988. Regulation of nod gene expression in Bradyrhizobium japonicum. Mol. Gen. Genet. 214:420-424.

Bellato, C., Krishnan, H. B., Cubo, T., Temprano, F., and Pueppke, S. G. 1997. The soybean cultivar specificity gene nolX is present, expressed in a nodD-dependent manner, and of symbiotic significance in cultivar-nonspecific strains of Rhizobium (Sinorhizobium) fredii. Microbiology 143:1381-1388.

Bullock, W. O., Fernandez, J. M., and Short, J. M. 1987. XL1-Blue: a high efficiency plasmid transforming recA Escherichia coli strain with $\beta$-galactosidase selection. Biotechniques 5:376-379.

Daniel, R. M., and Appleby, C. A. 1972. Anaerobic-nitrate, symbiotic and aerobic growth of Rhizobium japonicum: Effects on cytochrome P450, other haemoproteins, nitrate and nitrite reductases. Biochem. Biophys. Acta 275:347-54.

Figurski, D. H., and Helinski, D. R. 1979. Replication of an origin-containing derivative of plasmid RK2 dependent on a plasmid function provided in trans. Proc. Natl. Acad. Sci. U.S.A. 76:1648-52.

Freiberg, C., Fellay, R., Bairoch, A., Broughton, W. J., Rosenthal, A., and Perret, X. 1997. Molecular basis of symbiosis between Rhizobium and legumes. Nature 387:394-401.

Galán, J. E., and Collmer, A. 1999. Type III secretion machines: Bacterial devices for protein delivery into host cells. Science 284:1322-1328.

Galibert, F., Finan, T. M., Long, S. R., Pühler, A., Abola, P., Ampe, F., Barloy-Hubler, F., Barnett, M. J., Becker, A., Boistard, P., Bothe, G.,
Boutry, M., Bowser, L., Buhrmester, J., Cadieu, E., Capela, D., Chain, P., Cowie, A., Davis, R. W., Dréano, S., Federspiel, N. A., Fisher, R. F., Gloux, S., Godrie, T., Goffeau, A., Golding, B., Gouzy, J., Gurjal, M., Hernandez-Lucas, I., Hong, A., Huizar, L., Hyman, R. W., Jones, T., Kahn, D., Kahn, M. L., Kalman, S., Keating, D. H., Kiss, E., Komp, C., Lelaure, V., Masuy, D., Palm, C., Peck, M. C., Pohl, T. M. Portetelle, D., Purnelle, B., Ramsperger, U., Surzycki, R., Thébault, P., Vandenbol, M., Vorhölter, F.-J., Weidner, S., Wells, D. H., Wong, K., Yeh, K.-C., and Batut, J. 2001. The composite genome of the legume symbiont Sinorhizobium meliloti. Science 27:668-672.

Göttfert, M., Grob, P., and Hennecke, H. 1990. Proposed regulatory pathway encoded by the nodV and nod $W$ genes, determinants of host specificity in Bradyrhizobium japonicum. Proc. Natl. Acad. Sci. U.S.A. 87:2680-2684.

Göttfert, M., Holzhäuser, D., Bäni, D., and Hennecke H. 1992. Structural and functional analysis of two different nodD genes in Bradyrhizobium japonicum USDA110. Mol. Plant-Microbe Interact. 5:257-265.

Göttfert, M., Röthlisberger, S., Kündig, C., Beck, C., Marty, R., and Hennecke, H. 2001. Potential symbiosis-specific genes uncovered by sequencing a 410-kilobase DNA region of the Bradyrhizobium japonicum chromosome. J. Bacteriol. 183:1405-1412.

Gu, J., Balatti P. A., Krishnan, H. B., and Pueppke, S. G. 1997. Characterization of the overlapping promoters of $n o l B$ and $n o l W$, two soybean cultivar specificity genes from Rhizobium fredii strain USDA257. Mol. Plant-Microbe Interact. 10:138-141.

Hennecke, H., Günther, I., and Binder, F. 1982. A novel cloning vector for the direct selection of recombinant DNA in E. coli. Gene 19:231234.

Hueck, C. J. 1998. Type III protein secretion systems in bacterial pathogens of animals and plants. Microbiol. Mol. Biol. Rev. 62:379-433.

Kaneko, T., Nakamura, Y., Sato, S., Asamizu, E., Kato, T., Sasamoto, S., Watanabe, A., Idesawa, K., Ishikawa, A., Kawashima, K., Kimura, T. Kishida, Y., Kiyokawa, C., Kohara, M., Matsumoto, M., Matsuno, A. Mochizuki, Y., Nakayama, S., Nakazaki, N., Shimpo, S., Sugimoto, M., Takeuchi, C., Yamada, M., and Tabata, S. 2000. Complete genome structure of the nitrogen-fixing symbiotic bacterium Mesorhizobium loti. DNA Res. 7:331-338.

Kovács, L. G., Balatti, P. A., Krishnan, H. B. and Pueppke, S. G. 1995. Transcriptional organisation and expression of nolXWBTUV, a locus that regulates cultivar-specific nodulation of soybean by Rhizobium fredii USDA257. Mol. Microbiol. 17:923-933.

Krause, A., and Broughton, W. J. 1992. Proteins associated with root-hair deformation and nodule initiation in Vigna unguiculata. Mol. PlantMicrobe Interact. 5:96-103.

Krishnan, H. B., Kuo, C.-L., and Pueppke, S. G. 1995. Elaboration of flavonoid-induced proteins by the nitrogen-fixing soybean symbiont Rhizobium fredii is regulated by both nodD1 and nodD2, and is dependent on the cultivar-specificity locus, nolXWBTUV. Microbiol. 141:2245-2251.

Kündig, C. 1994. Untersuchungen zur Genomstruktur und Charakterisierung des einzigen rRNA-Operons von Bradyrhizobium japonicum Ph.D. thesis. Eidgenössische Technische Hochschule, Zürich, Switzerland.

Loh, J., Garcia, M., and Stacey, G. 1997. NodV and NodW, a second flavonoid recognition system regulating nod gene expression in Bradyrhizobium japonicum. J. Bacteriol. 179:3013-3020.

Loh, J. T., Yuen-Tsai, J. P., Stacey, M. G., Lohar, D., Welborn, A., and Stacey, G. 2001. Population density-dependent regulation of the Bradyrhizobium japonicum nodulation genes. Mol. Microbiol. 42:3746.

Long, S. R. 2001. Genes and signals in the Rhizobium-legume symbiosis. Plant Physiol. 125:69-72.

Marie, C., Broughton, W. J., and Deakin, W. J. 2001. Rhizobium type III secretion systems: Legume charmers or alarmers? Curr. Opin. Plant Biol. 4:336-342.

Meinhardt, L. W., Krishnan, H. B., Balatti, P. A., and Pueppke, S. G. 1993. Molecular cloning and characterisation of a sym plasmid locus that regulates cultivar-specific nodulation of soybean by Rhizobium fredii USDA257. Mol. Microbiol. 9:17-29.

Minton, N. P. 1984. Improved plasmid vectors for the isolation of translational lac gene fusions. Gene 31:269-273.

Norrander, J., Kempe, T., and Messing, J. 1983. Construction of improved M13 vectors using oligodeoxynucleotide-directed mutagenesis. Gene 26:101-106.

Regensburger, B., and Hennecke, H. 1983. RNA polymerase from Rhizobium japonicum. Arch. Microbiol. 135:103-109.

Sambrook, J., Fritsch, E. F., and Maniatis, T. 1989. Molecular cloning: A laboratory manual. 2nd ed. Cold Spring Harbor Laboratory Press, Cold Spring Harbor, NY, U.S.A

Sadowsky, M. J., Tully, R. E., Cregan, P. B., and Keyser, H. H. 1987. Ge- 
netic diversity in Bradyrhizobium japonicum serogroup 123 and its relation to genotype-specific nodulation of soybean. Appl. Environ. Microbiol. 53:2624-2630.

Simon, R., Priefer, U., and Pühler, A. 1983. Vector plasmids for in-vivo and in-vitro manipulation of Gram-negative bacteria. Pages 98-106 in: Molecular Genetics of the Bacteria-Plant Interaction, A. Pühler, ed. Springer Verlag, Berlin.

Somasegaran, P., and Hoben, H. J. 1994. Handbook for rhizobia-Methods in legume-rhizobial technology. Springer Verlag, Berlin, Germany.

Sullivan, J. T., Trzebiatowski, J. R., Cruickshank, R. W., Gouzy, J., Brown, S. D., Elliot, R. M., Fleetwood, D. J., McCallum, N. G., Rossbach, U., Stuart, G. S., Weaver, J. E., Webby, R. J., De Bruijn, F. J., and Ronson, C. W. 2002. Comparative sequence analysis of the symbiosis island of Mesorhizobium loti strain R7A. J. Bacteriol.
184:3086-3095.

Vincent, J. M. 1970. A manual for the practical study of root-nodule bacteria. Blackwell Scientific Publications, Oxford, England.

Viprey, V., Del Greco, A., Golinowski, W., Broughton, W. J., and Perret, X. 1998. Symbiotic implications of type III protein secretion machinery in Rhizobium. Mol. Microbiol. 28:1381-1389.

\section{AUTHOR-RECOMMENDED INTERNET RESOURCES}

National Center for Biotechnology Information: http://www.ncbi.nlm.nih. gov/BLAST/

INRA Multiline multiple sequence alignment page: http://prodes. toulouse.inra.fr/multalin/multalin.html 